\title{
THE 133RD LIVE PODCAST OF THE GOURMANDO RESISTANCE
}

\section{A taste of freedom.}

\section{BY BETH CATO}

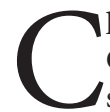

laudia had been a devotee of the Gourmando Resistance Podcast since episode 20. She knew what to do as hostess. She knew she may not have much time to do it. Her battery-operated stove burner was assembled, the large pot atop it half full of oil at approximately $180^{\circ} \mathrm{C}$. Her dough was mixed. Half of it was loaded into an old plastic device that, oddly enough, was called a gun, although this device extruded dough in various shapes and sizes, depending on the disc that was loaded into the end.

And, most importantly for the podcast, she had on her full synth suit, complete with a gustatory sheath on her tongue. But for the first time, she was going to output data, not receive.

Through the overlay on her enhanced contacts, she stared at the camera mounted above her makeshift kitchen. With the movement of her eyes, she signalled the programme to go live.

"Greetings, fellow Gourmet Commandos! Welcome to the 133rd Live Podcast. I'm Claudia." She showed off the plastic gun with its dough-filled tube. "I'm making a dessert my grandma remembered from her childhood: churros."

She bit back the urge to babble nervously. She had to get cooking. Nutrition enforcers spied on the Gourmando forums online, and they might be watching her even now. Her face was mostly bare - part of the defiance of the broadcast, and the risk. If she was identified via facial or retinal recognition software, officers could be at her door in minutes.

It was impossible to know how many 'casters were busted, but very few hosted multiple episodes.

Claudia pulled the trigger on the gun to release a fat, star-shaped tube of dough into the oil. It baffled her that people cooked food in the old days using a method that smelt so awful. Things were so different before the famines and strict caloric monitoring, before daily rations of government-issued AllFood loaves in five flavours.

"This churro dough is simple, just flour, sugar, salt, butter, water and eggs." She squirted more dough into the oil. "Thank you to everyone who sent ingredients and tools."

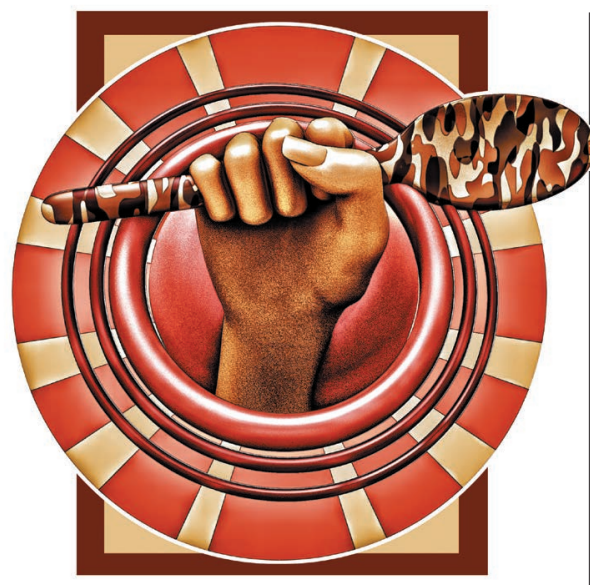

Gourmandos had contributed supplies, as they always did. Hundreds, maybe thousands of people, tuned in for these broadcasts to experience illicit foods of yore. Everyone stayed anonymous until they volunteered to take a turn at the camera. Each time Claudia had checked her assigned drop-box locations around the city in recent weeks, she'd wondered if she'd find ingredients, kitchen implements or a trap.

"The churros are turning brown fast," Claudia said. "Oh! I almost forgot." She set down the gun and touched the dough still in the bowl, letting the sensors in her fingertips share the data with everyone else who wore synth suits. Those people already knew her armpits were getting downright swampy.

In a sudden fit of bravado, she pinched off some dough and brought it near her mouth. She could imagine the horror of many of her viewers. Some might even be ripping the sensor sheaths from their tongues, repulsed by the idea of experiencing raw ingredients, especially eggs.

But she remembered the giddy delight she'd felt when a previous podcaster had shared raw chocolate-chip cookie dough. Claudia had thought the dough had tasted even better than the fresh-baked cookies.

The churro dough wasn't anywhere near as delightful. She almost spat it out, but after a few quick chews, she swallowed.

"I think the churros are done now." She used a slotted spoon to transfer them to a towel on a plate. Some churros were curved, whereas others were fairly straight. Strangely enough, the oil smelt good now. She breathed in deeply, allowing the foreign scent to drift through the filters over her nose and to her fellow foodies.

Claudia glanced at the clock. Not even ten minutes had passed. She hesitated, tempted to start more dough in the oil, but no. She needed to finish the first batch. She couldn't miss the chance to experience what her grandmother had told her about in a creaky voice so full of yearning.

A quick tap confirmed a churro was just cool enough to touch. She tossed it into a prepared bowl mounded with cinnamon and sugar, and rolled the churro around for an immersive baptism. The incredible sweet and spicy scent made her eyes and mouth water.

Claudia brought the completed churro to her lips. After a lifetime of living on AllFood loaves, of vicariously tasting the forbidden through the podcast, she was going to ingest contraband calories for herself.

She bit into the tip of the churro. The coating of sugar and cinnamon dazzled her tongue as her teeth crunched through the outer ridges to find an interior that was soft, chewy and delightfully hot. She took another bite and wept. Salty tears joined the divine flavours in her mouth.

"I'm eating a churro, Abuelita," she whispered.

A heavy knock shuddered through the door.

No. No. No -

An instant later, the digital locks were overridden. Officers in armoured suits burst in, guns in hand - and these guns weren't loaded with dough. She froze, overwhelmed. She'd read so many theories about what happened from here: hidden tribunals, imprisonment, prosecution. That rebellious 'casters were probably stripped of their enhancements, forevermore isolated from the expansive digital world.

But she had experienced churros, and so much more. This had been worth it.

She shoved the rest of the churro in her mouth. "Keep cooking, Gourmandos!" she shouted. Crumbs sprayed from her mouth as she held high a fist that sparkled with sugar. Her head was slammed into the table a second later. Through dizzying pain, she swallowed, and smiled..

Beth Cato resides in Arizona. She's the author of both The Clockwork Dagger duology and Blood of Earth trilogy published by Harper Voyager. Her website is BethCato.com. 